\title{
PENGOPERASIAN JARING ARAD DI PERAIRAN PANTAI UTARA JAWA: MASALAH DAN PENYELESAIANNYA
}

\author{
Ratna Indrawasih dan Ary Wahyono ${ }^{1}$ \\ ${ }^{1}$ Peneliti pada Pusat Penelitian Kemasyarakatan dan Kebudayaan - Lembaga IImu Pengetahuan Indonesia \\ Widya Graha LIPI, It. VI \& IX \\ I. Gatot Subroto, Jakarta 12710 \\ Tel / fax : 021 - 5251542 / 5701232
}

\begin{abstract}
ABSTRAK
Artikel tentang pengoperasian jaring arad di perairan Pantai Utara Jawa: problem dan penyelesaiannya ini membahas masalah konflik kenelayanan, terutama permasalahan yang berkaitan dengan penggunaan jaring arad di perairan Pantai Utara Jawa Tengah dan Jawa Barat. Artikel ini merupakan hasil penelitian yang mengambil lokasi di Kabupaten Rembang dan Cirebon. Penelitian tersebut dilakukan dengan pendekatan kualitatif. Hasil penelitian menunjukkan penangkapan udang dengan menggunakan jaring semi trawl merupakan suatu fenomena sosial yang menunjukkan tidak ada alternatif lain bagi nelayan dalam mencari sumber kehidupan. Fenomena ini juga menunjukkan telah terjadi jalan pintas dan bersifat jangka pendek tanpa melihat dampak-dampak yang ditimbulkan baik dari segi sosial, ekonomi dan lingkungan. Upaya untuk mengatasi problem penggunaan jaring arad di Pantura tampaknya tidak mudah. Pemerintah telah mengeluarkan peraturan yang melarang penggunaan jaring arad. Akan tetapi tampaknya kebijakan pelarangan alat tangkap tersebut menghadapi masalah pada implementasi di lapangan. Penegakan hukum belum bisa dilakukan secara optimal. Hal ini antara lain disebabkan masih pasifnya para petugas dalam mengontrol terjadinya pelanggaran, dan keberadaan petugas tidak didukung oleh prasarana yang memadai. Jadi ada kesan bahwa pelarangan alat tangkap tersebut tidak mendapat dukungan dari aparat penegak hukum, sehingga masalah yang berkaitan dengan penggunaan alat tangkap yang sudah dilarang tersebut tidak dapat terselesaikan secara tuntas.
\end{abstract}

Kata Kunci: Konflik Kenelayanan, Permasalahan Perikanan Pantai, Arad-Semi Trawl

\section{Abstract : The Operation of Arad Net in The North Coast of Java: Problems and Their Solutions. By: Ratna Indrawasih and Ary Wahyono.}

The article of "The Operation of Arad Net in The North Coast of Java: Problems and their Solution" discusses the problem of fishers conflict especially related to the usage of arad net in North Coast of Central Java and West Java. This article was conducted in Rembang and Cirebon Regencies. Qualitative approach was used in the research. Results showed that the exploitation of shrimps using a semi-trawl called 'jaring arad' was considered a social phenomenon of fishing to cope daily life. This phenomenon also shows that there was a short term profit orientation without considering long-term impact on social, economic and environment aspects. The effort to reduce the used of arad in Pantura was not easy. Government has erected the regulation on banning the used of arad. However, low enforcement was quite weak. This is because the officer could not effectively control territory and was not supported by adequate infrastructure and equipments. That is why, it seemed that regulation on banning the use of arad was not supported by adequate enforcement efforts. Hence, problem related the use of Arad could not be solved effectively.

\section{Keywords : Fisher's Conflict, Inshore Fishing Problems, Arad-Semi Trawl}




\section{PENDAHULUAN}

Gejala padat tangkap yang terjadi di sejumlah perairan Indonesia, merupakan dampak dari penyebaran armada kapal perikanan yang belum tertata secara profesional dalam memanfaatkan sumber daya ikan. Manggabarani (2006) mengatakan bahwa kondisi ketidakmerataan pemanfaatan sumber daya ikan itu sudah lama terjadi di beberapa daerah penangkapan ikan (fishing ground) a.I. di Selat Malaka, Pantai Utara Jawa dan Pantai Selatan Sulawesi (http://www.bisnis.com/servlet/page? _pageid=477\&_dad porta 130 \& schema $=$ PORTAL30\&pared_id $=435837 \& p$ atop id=W09).

Kondisi tersebut membuat nelayan yang tinggal di Pantai Utara Pulau Jawa (Pantura) berada dalam posisi yang sulit, dan tidak menguntungkan. Hal ini disebabkan padatnya penangkap ikan (over-fishing), wilayah perairan utara Pulau Jawa tidak memungkinkan lagi dikembangkan perikanan pantai (inshore fishing). Upaya-upaya untuk mengatasi over fishing di Pantura dihadapkan pada keterbatasan akses permodalan dan teknologi. Akhirnya, terjadi kepadatan jumlah nelayan yang beroperasi di perikanan pantai, yang mengakibatkan hasil tangkapan ikan oleh para nelayan berkurang. Kurangnya hasil tangkapan menyebabkan pendapatan mereka juga berkurang.

Bila terjadi konflik antar nelayan yang menggunakan alat tangkap yang sama, konflik ini disebut konflik perebutan sumberdaya. Apalagi antara nelayan yang menggunakan alat yang berbeda, walaupun mungkin sumberdaya yang ditangkap berbeda, tetapi karena berada pada wilayah yang sama, maka bisa terjadi konflik cukup besar. Konflik yang terakhir selain dikatakan sebagai konflik penggunaan alat tangkap juga disebut konflik perebutan wilayah.

Sementara itu, disisi lain, nelayan Pantura yang mampu mengembangkan perikanan lepas pantai dengan armada purseseine, seperti nelayan dari Pekalongan dan
Juwana (Pati) yang selalu dituduh melakukan eksploitasi sumberdaya ikan berlebihan di wilayah perairan nelayan Kalimantan, Sumatera, Sulawesi. Akibatnya terjadi penolakan nelayan purse seine dari Pantura yang cenderung mengakibatkan konflik kenelayanan. Contohnya, seperti kasus pembakaran kapal purse seine milik nelayan dari Jawa Tengah di perairan Kalimantan Selatan dan Masalembo, atau nelayan Jawa Tengah yang melaut di Selat Makasar ditakuttakuti dengan cara meledakkan bom beberapa meter dari kapal nelayan Jawa Tengah, dengan tujuan agar nelayan Jawa Tengah berhenti mencari ikan di Selat Makasar dan kembali ke daerah asal mereka.

Berkurangnya sumberdaya ikan yang ada di wilayah penangkapannya, juga menyebabkan nelayan pantura Jawa berlomba memperebutkan sumberdaya tersebut dengan menciptakan alat tangkap yang dianggap bisa meningkatkan hasil tangkapan, maka nelayan pantura membuat modifikasi alat tangkap yang menyerupai trawl yang disebut jaring arad (di Cirebon) dan cotok di Rembang. Arad/cotok adalah jaring berbentuk kantong yang menggunakan alat sepasang pembuka mulut (board) yang ditarik perahu bermotor. Jaring udang tersebut biasa dioperasikan di perairan di jalur penangkapan I pada kedalaman 6 - 10 meter dengan jarak 2-3 mil dari daratan.

Penangkap ikan jenis jaring semi trawl atau sering disebut jaring arad tersebut, hingga sekarang masih digunakan nelayan di sepanjang pantai utara (pantura). Hasil penelitian Hamdan (2007) yang dikutip oleh Yuhka Sundaya mengungkapkan bahwa meski dalam data statistik perikanan Kabupaten Indramayu, alat tangkap arad tidak terdaftar, namun pada kenyataannya di lapangan masih banyak ditemukan nelayan yang menggunakan alat tangkap arad (http://mukhtarapi.blogspot.com/2009/03/fakt a-illegal-fishing-di-indramayu-dan.html). Sementara Kompas (19 Februari 2009) dikutip Sundaya (2009) memberitakan bahwa di salah satu bagian wilayah Kecamatan 
Kandanghaur, yaitu Desa Eretan Kulon. Menurut Royani, Sekretaris KUD Nelayan Mina Bahari, sekitar 400 perahu dari total 800 perahu memakai jaring arad.

Beberapa permasalahan terkait dengan jaring arad antara lain adalah apa alasan nelayan pantura menggunakan jaring arad? apakah ada ketidakjelasan kriteria jaring yang dilarang, sehingga masyarakat menganggap hanya trawl yang dilarang, sehingga mereka menggunakan arad? Apa akibat yang timbul dengan penggunaan arad? Bagaimana penyelesaiannya? Tulisan ini akan membahas permasalahan yang berkaitan dengan penggunaan jaring arad di perairan Kabupaten Rembang, Jawa Tengah dan Cirebon, Jawa Barat.

Diharapkan artikel ini akan dapat memperkaya tulisan-tulisan tentang permasalahan kenelayanan di Indonesia, khususnya berkaitan dengan konflik nelayan.

\section{METODOLOGI}

Data yang digunakan dalam tulisan ini merupakan bagian hasil penelitian yang penulis lakukan di Rembang, yaitu pada penelitian tentang Kebijakan Pengelolaan Sumberdaya Laut pada tahun 2003, serta penelitian Pemberdayaan Masyarakat Nelayan di Cirebon pada tahun 2000. Di samping data dari hasil penelitian tersebut, tulisan ini juga menggunakan data yang merupakan berita dalam media massa (surat kabar) maupun artikel yang diakses melalui media elektronik (internet).

\section{Pendekatan penelitian}

Penelitian yang berlokasi di Kabupaten Rembang dan Cirebon tersebut dilakukan dengan pendekatan kualitatif. Oleh karena itu data yang dikumpulkan difokuskan pada data kualitatif. Demikian pula cara pengumpulan dan pengolahan data serta analisanya dilakukan dengan menggunakan prinsipprinsip pendekatan kualitatif.

Metode pengumpulan data
Data yang dikumpulkan dalam penelitian tersebut terdiri dari data primer dan data sekunder. Data sekunder diperoleh dari kajian pustaka, baik yang bersifat teknik seperti laporan hasil penelitian maupun yang teknik seperti buku atau artikel baik berupa makalah maupun kliping surat kabar dan data yang diperoleh dari instansi pemerintah (Dinas Kelautan dan Perikanan).

Untuk pengumpulan data primer, dilakukan dengan pendekatan kualitatif, melalui metode wawancara mendalam (in deep interview). Wawancara dipandu dengan pedoman wawancara, dan dengan merekam wawancara menggunakan alat perekam suara atau tape recorder.

Wawancara dilakukan terhadap informan kunci di lokasi penelitian seperti yang telah disebutkan di atas, yang terdiri dari pejabat Dinas Kelautan dan Perikanan, BAPPEDA (Badan Perencanaan Pembangunan Daerah), masyarakat (nelayan) dari berbagai jenis alat tangkap, petugas KUD, Himpunan Nelayan Seluruh Indonesia (HNSI), LSM dan kalangan akademisi (perguruan tinggi). Informan kunci dipilih secara purposive dan cara snowball sampling.

Untuk melengkapi metode wawancara, dilakukan pula observasi. Observasi dilakukan untuk mengamati suasana di lokasi-lokasi kegiatan nelayan, yaitu di fishing ground nelayan, tempat pendaratan ikan (PPI) serta sentra-sentra perdagangan ikan (TPI). Cara ini dimaksudkan untuk melengkapi teknikteknik di atas, guna memperjelas kebenaran hasil wawancara serta untuk mengetahui halhal yang tidak dapat diperoleh melalui wawancara, tetapi dapat diketahui melalui pengamatan.

\section{Analisa data}

Setelah dilakukan transkrip data primer yang diperoleh melalui wawancara dan direkam, maka dilakukan analisis terhadap data primer dan data sekunder. Analisis data dilakukan secara deskriptif interpretatif. 


\section{HASIL DAN PEMBAHASAN}

\section{Pengoperasian Arad di Pantura}

Arad atau cotok atau krakad merupakan alat tangkap udang yang umumnya digunakan nelayan perairan Pantai Utara Jawa (Pantura). Penggunaan jaring Cotok oleh nelayan Jawa Tengah tersebar di Kab. Rembang, Jepara, Kendal, Batang, Tegal, Kebumen, Pati, Demak, Pemalang, Pekalongan, Brebes, dan Cilacap. Di Kabupaten Cirebon, penggunaan arad berkembang sejak awal tahun 1987, yaitu seiring dengan meningkatnya pasar udang untuk ekspor. Hal itu sejalan dengan direncanakannya program nasional Protekan (Program Nasional Peningkatan Hasil Ekspor Perikanan). Dengan meningkatnya permintaan hasil laut (udang) di pasaran luar negeri melalui eksport, maka harga udang menjadi naik dan ditambah cara memasarkannya pun mudah (melalui perusahaan ekspor), sehingga membuat nelayan bergairah untuk menangkap udang. Untuk menangkap udang di perairan 6-10 meter harus digunakan alat tangkap trawl. Akan tetapi karena trawl dilarang dioperasikan di wilayah perairan tersebut, maka nelayan pantura menggunakan jaring modifikasi tersebut.

Sebenarnya, melihat karakteristik alat tangkap seperti itu, jenis jaring arad tersebut ada yang memasukkan ke dalam kategori trawl (beam trawl), terlebih daerah operasi alat tangkap ini tidak jauh berbeda dengan wilayah operasi trawl yang disebutkan dalam SK. Mentan Pertanian No. 607/1976 dan Keppres 39/1980. Akan tetapi, mengapa nelayan mengunakan arad? Karena udang dasar sulit ditangkap tanpa menggunakan alat tangkap jenis ini. Bagi nelayan Pantura, arad merupakan jenis alat tangkap yang tidak ada penggantinya dilihat dari sisi kemampuannya untuk menjaring udang dan ikan-ikan demersal yang bergerombol. Dengan alat tersebut, nelayan pantura sangat mudah menjaring udang di perairan yang memiliki kedalaman sekitar 6-10 meter. Apalagi, menurut Kepala Dinas Perikanan Jawa Barat, biaya pembuatan jaring arad lebih murah, hanya sekitar 1,5 juta rupiah, sehingga nelayan kecil lebih suka menggunakan jaring tesebut (Kompas, 07/06/06).

Di samping itu, belum ada alat tangkap pengganti yang sebaik jenis alat tangkap ini. Oleh sebab itu, nelayan pengguna arad mengakui bahwa arad merupakan modifikasi jaring trawl sebagai taktik nelayan untuk mengelabui Keppres 30/1980 tentang larangan pengunaan trawl. Dengan modifikasi tersebut, nelayan dapat tetap menggunakan trawl tetapi berukuran kecil dan dapat menyesuaikan kondisi perairan dengan kedalaman pantai, sehingga lebih mudah dioperasikan dan dapat menjangkau setiap sudut perairan pantai.

Oleh karena itu, sebenarnya modifikasi alat tangkap (mini trawl) yang dilakukan nelayan kecil sebenarnya merupakan akses dari penerapan Keppres 30/1980. Keppres $30 / 1980$ dianggap terlalu diskriminatif. Penerapan Keppres 30/1980 memberi kesan bahwa nelayan kecil tidak diperbolehkan menangkap udang, sementara nelayan besar justru dilindungi. Kelemahan Keppres 30/1980 menyebabkan sebagian pengusaha besar tetap dapat mengoperasikan trawl, sementara nelayan kecil sulit memperoleh kesempatan karena lantaran tidak memiliki akses seperti pengusaha.

\section{Akibat Pengoperasian Jaring Arad}

Penggunaan jaring arad/Cotok/krakad meresahkan kelompok nelayan lain (yang tidak menggunakan jaring tersebut) dan mendapat protes oleh mereka karena dianggap menguras sumberdaya ikan di perairan pantura. Alat tangkap tersebut dianggap yang menyebabkan sumberdya di dasar laut terkeruk, termasuk anak ikan yang belum layak di tangkap. Begitu pula terumbu karang yang menjadi tempat ikan berkembang biak dan jaring nelayan tradisional lainnya menjadi rusak akibat terseret oleh gerakan 
jaring arad tersebut. Dari pengakuan nelayan tradisional di pantura diketahui bahwa dulu dengan perahu bermesin 16 PK penghasilan rata-rata paling tidak $\mathrm{Rp} 10.000,-/$ hari. Tetapi, sejak kehadiran nelayan arad (cotok) dan nelayan cantrang, pendapatan setiap nelayan paling tinggi Rp 6.000,-/hari. Masalahnya bukan hanya penghasilan mereka saja, melainkan masa depan nelayan di daerah ini karena sumber perikanan dikuras oleh jaring arad. Belum lagi kerusakan jaring mereka yang harus diperbaiki setiap kali setelah dilalui jaring arad. Semua keluhan nelayan tradisional tersebut, diakui oleh nelayan jaring arad. Mereka sadar dan merasakan betul penurunan produksi perikanan di daerahnya. Namun, ia tidak mau sepenuhnya dipersalahkan, karena sejak lima tahun silam sebelum arad dioperasikan, banyak nelayan menggunakan jaring cantrang. Pemakaian jaring cantrang tidak ada bedanya dengan jaring arad. Hanya saja, pengoperasian jaring cantrang hanya menimbulkan keluhan di kalangan nelayan tradisional, tidak sampai menimbulkan konflik langsung dengan nelayan lainnya. Ini disebabkan, jaring cantrang yang juga menguras sumberdaya perikanan, tidak sampai mengganggu atau menyebabkan jaring nelayan lain rusak. (Kompas, Selasa 15 Mei 2001).

Di Cirebon, dari keterangan informan pada kesempatan penelitian bahwa penggunaan arad dinilai merusak jaring kejer, yang digunakan untuk menjaring rajungan. Jaring kejer wilayah operasinya sama dengan jaring arad yaitu di jalur I dan II, maka jaring kejer yang terpasang sering tergaruk oleh jaring arad. Walaupun untuk menghindarinya sudah dipasang tanda-tanda yang menunjukkan bahwa di tempat itu ada jaring kejer, akan tetapi karena pengoperasian jaring arad pada malam hari maka tanda-tanda adanya jaring kejer sering tidak kelihatan sehingga jaring kejer tetap tergaruk atau bahkan sengaja digaruk. Oleh karena itu, dengan dioperasikannya jaring arad, maka jaring kejer sering rusak atau bahkan hilang.
Tidak hanya jaring kejer yang hilang, bahkan rumpon pun kadang ikut tersapu. Selain menggaruk jaring kejer atau rumpon juga merusak lingkungan. Ini disebabkan lebar mata jaring arad yang terlalu kecil hanya setengah inci, sehingga dapat menguras segala ukuran jenis biota laut, sehingga dapat mempengaruhi keberadaan stok sumberdaya ikan di perairan Cirebon. Akibatnya selain meresahkan nelayan lain, penggunaan jaring arad juga menimbulkan konflik. Sundaya, (2009) mengutip berita dalam Pikiran Rakyat (19/09/2002) di Kecamatan Kandanghaur dan Cantigi, Kabupaten Indramayu terjadi konflik antar nelayan yang merupakan akumulasi masalah sosial-ekonomi dari dua tahun sebelumnya. Konflik tersebut terjadi karena perebutan wilayah penangkapan ikan, protes penggunaan jaring arad dan garok.

Di Jawa Tengah, konflik terjadi baik antar kelompok nelayan dari kabupaten yang sama maupun antar kelompok nelayan dari kabupaten yang berbeda. Potensi konflik penggunaan arad sebenarnya sudah berlangsung sebelum tahun 1980-an, yaitu sebelum dikeluarkannya Keppres 39/1980, namun mulai terjadi konflik terbuka pada tahun 2000. Dari keterangan informan pada penelitian lapangan di Rembang, diperoleh informasi beberapa kasus konflik yang pernah terjadi antara lain di Jepara, konflik meledak ketika rombongan nelayan Jepara Selatan yang sedang menangkap ikan digeledah oleh nelayan Jepara Utara. Penggeledahan dilakukan karena nelayan Jepara Selatan diketahui telah menggunakan jaring cotok di perairan Keling Jepara, perairan yang menjadi lokasi penangkapan nelayan Jepara Utara. Tindakan nelayan Jepara Utara ini menyebabkan tawuran antara kedua kelompok nelayan yang mengakibatkan jatuh korban luka-luka dan tewas di pihak nelayan Jepara Selatan. Ada sekitar 10 orang nelayan yang mengalami luka dan 2 orang hilang. Pada hari yang lain, kelompok nelayan Jepara Selatan melakukan penyanderaan 8 orang nelayan Jepara Utara sebagai bentuk 
solidaritas atas penyerangan terhadap rekannya, dan menuntut pengembalian 2 (dua) rekannya yang hilang saat dilakukan razia penangkapan ikan. Nelayan yang disandera diserahkan ke Mapolsek Keling dan selanjutnya diamankan di Mapolres Jepara. Sebagai rasa solidaritas nelayan Jepara Utara terhadap rekannya yang disandera, maka 150 orang nelayan Jepara Utara mendatangi Polres Jepara meminta agar rekannya dibebaskan.

Konflik antar kelompok nelayan yang terjadi di Desa Balong, Kecamatan Bangli juga mengakibatkan seorang nelayan meninggal dunia. Peristiwa lain juga terjadi di perairan Keling yang juga mengakibatkan seorang nelayan meninggal dunia akibat dikeroyok sekelompok orang tidak dikenal. Konflik ini terjadi antara nelayan Desa Ujung Batu dan Desa Jobokuto yang berhadapan dengan nelayan Desa Bandungharjo Keling. Konflik penggunaan jaring cotok ini juga melibatkan nelayan Rembang. Akibat dari konflik nelayan ini adalah terbakarnya sebuah perahu milik nelayan asal Kota Rembang dibakar massa di halaman Pelabuhan Pendaratan Ikan (PPI) Ujungbatu, Kota Jepara. Selain pembakaran perahu, lima nelayan Rembang menjadi sasaran amukan nelayan Ujung Batu dan Jobokuto yang dianggap sebagai nelayan Desa Banggi, Kecamatan Kota Rembang. Saat itu, nelayan desa Banggi Rembang dituduh sebagai pengeroyok nelayan Jepara sehingga menyebabkan tewasnya seorang nelayan.

Masalah jaring cotok ini juga menyebabkan konflik antar nelayan lokal (sesama nelayan Rembang), yaitu antara nelayan Desa Bonang, Kecamatan Lasem yang pro jaring cotok dengan nelayan Desa Banggi dan Desa Pangkalan, Kecamatan Sluke yang kontra jaring cotok. Selain itu juga antara nelayan rajungan dari Desa Pondok (Kecamatan Sluke) dengan nelayan jaring cotok dari Kecamatan Kragan. Konflik dimulai ketika pada suatu malam nelayan Pondok merusak jaring cotok nelayan Karagan.
Kemudian pada malam berikutnya nelayan Karagan membalas dengan menyandra nelayan Pondok. Akhirnya terjadi konflik fisik yang menyebabkan banyak korban luka berat.

Sementara itu di Tegal terjadi konflik terbuka antara nelayan arad Muarareja dengan nelayan jaring gill net di perairan sebelah utara sekitar tiga mil dari garis pantai Kecamatan Surodadi, tepatnya di perairan sekitar Karang Jeruk pada 7 Maret 2000 yang penyelesaiannya berlarut hingga Mei 2000. Selain itu, terjadi konflik antara nelayan jaring arad dengan nelayan jaring nilon di perairan Tanjungsari, Kabupaten Pemalang, Oktober 2000. Lalu konflik antara nelayan jaring arad dan nelayan jaring nilon di perairan Jepara pada bulan Agustus 2000, antara nelayan Jepara Tengah dan Jepara Selatan dengan nelayan seputar Keling, di perairan Todanan Keling (Jepara) (Kompas, Selasa 21 Mei 2001).

Memahami konflik yang terjadi tersebut, kecenderungannya adalah disebabkan oleh penggunaan alat tangkap yang berbeda, maka menurut pola konflik menurut Charles (1992) termasuk kategori konflik ketiga, yaitu yang disebut internal allocation (alokasi internal). Konflik dalam kategori ini meliputi konflikkonflik yang lahir sebagai akibat dari interaksi antara berbagai stakeholder yang terlibat dalam usaha perikanan. Konflik-konflik dalam kategori ini adalah konflik antara kelompok nelayan dengan latar belakang geografis dan kultural berbeda, antara nelayan dengan alat tangkap berbeda dan antara nelayan penangkap dengan pihak-pihak yang terlibat pada proses pasca-panen atau pemasaran.

\section{Penyelesaian Masalah Pengoperasian Arad}

Dalam menanggapi keresahan nelayan Cirebon, Pemerintah Provinsi daerah Tingkat I Jawa Barat mengeluarkan Surat Keputusan Kepala Dinas Perikanan Propinsi Daerah Tingkat I Jaw a Barat No. 523.41/12597/Binkop, tanggal 9 Nopember 1992 perihal jaring arad. Dalam surat 
keputusan tersebut disebutkan bahwa jaring yang dalam pengoperasionalannya menggunakan palang/beam/ pembuka mulut adalah dilarang. Bertolak dari batasan tersebut maka kecuali trammel net, jaring yang menggunakan pembuka mulut seperti jaring kantong, jaring arad, lampara dasar adalah termasuk yang dilarang.

Dengan dikeluarkannya SK tersebut, maka kemudian dilakukan langkah-langkah penertiban pengoperasian jaring arad di seluruh perairan Cirebon, yang dilakukan oleh beberapa instansi terkait yaitu Dinas Perikanan Pemda, Polairud dan Angkatan Laut. Adanya penertiban tersebut, maka banyak jaring arad yang disita dan dibakar. Namun demikian, tampaknya nelayan pengguna jaring arad tidak jera, karena adanya razia tersebut bukan menghilangkan penggunaan jaring tersebut, melainkan malah semakin banyak hingga dapat dijumpai di hampir seluruh perairan Cirebon. Puncak dari keresahan masyarakat, pada tahun 1994 masyarakat melakukan protes dengan menulis surat kepada wakil presiden melalui kotak pos 5000 yang berisi tentang merajalelanya pengoperasian pukat harimau di perairan pantai Cirebon. Surat tersebut ditembuskan kepada Gubernur KDH Tk I Jawa Barat dan Bupati KDH Tk II Cirebon. Akhirnya pada tahun itu juga dilakukan lagi penertiban jaring arad oleh instasi terkait, dan hasilnya banyak jaring arad yang disita dan dibakar.

Intansi yang memiliki kewenangan untuk menindak pelanggaran penggunaan jaring yang dilarang dioperasikan adalah Gubernur. Gubenur biasanya lalu mengeluarkan instruksi kepada Bupati Kepala Daerah Tingkat II untuk melakukan penindakan terhadap pelanggaran penggunaan alat tangkap. Sebagai contoh, penindakan Bupati Kepala Daerah Tingkat II Cilacap yang telah mengambil langkah menangkap kapal yang menggunakan jaring arad dan mengajukan kepada institusi pengadilan. Peranan, Dinas Perikanan Propinsi hanya sebatas memberikan penjelasan teknis apa yang disebut dengan jaring cotok. Penindakan penggunaan alat tangkap yang dianggap merusak lingkungan, seperti trawl dilakukan secara terpadu yang melibatkan semua unsur pemerintah dan masyarakat. Penindakan secara terpadu dalam bentuk tim gabungan di bawah koordinasi Pemerintah Daerah. Unsur-unsur lain yang terlibat adalah Kodim, Polres, Kejaksaan, Dinas Perikanan, Pemerintah Kecamatan, dan Kepala Desa yang bersangkutan. Unsur masyarakat diwakili oleh KUD dan HNSI.

Di dalam pengelolaan sumberdaya perikanan, nelayan merupakan partisipan utama. Nelayan memegang peranan penting dalam pengambilan keputusan setiap kebijaksanaan, perencanaan, alokasi dan penyelenggaraan serta pengawasan. Belakangan ini juga telah terbentuk forum Koordinasi Pengelolaan Pemanfaatan Sumberdaya Ikan (FKPPS). Forum Nasional yang terdiri dari unsur Pemerintah, Perguruan Tinggi, HNSI, MPN. Forum ini akan dibentuk untuk tingkat propinsi dan kabupaten/kotamadya. Salah satu rekomendasi yang dihasilkan di kota Cirebon adalah tetap mempertahankan Keppres 38/1980.

Pemerintah Daerah Jawa Tengah sebenarnya terlambat merespon pelarangan penggunaan arad. Enam tahun setelah dikeluarkan Keppres 39/80 tentang trawl, baru dikeluarkannya SK. Gubernur No. $523.4 / 285 / 1986$ pelarangan trawl di perairan Jawa Tengah. Kemungkinan Pemda Jateng terlambat merespon pelarangan cotok terkait dengan penerapan kriteria trawl pada jaring cotok. Perdebatan kriteria apakah jaring cotok termasuk trawl cukup menyita waktu, sementara keresahan nelayan terus berlangsung.

Pemerintah daerah mengaku masih terbatas memberikan penjelasan teknis tentang jenis-jenis dan ukuran alat tangkap yang dilarang. Upaya ini dilakukan oleh Dinas Perikanan Kabupaten/Kotamadya melalui pendekatan pembinaan atau penyuluhan 
terhadap kelompok-kelompok nelayan yang menggunakan alat tangkap yang merusak tersebut. Penegakan hukum terhadap penggunaan Jaring cotok tidak dapat dilakukan oleh Dinas Perikanan Kabupaten/Kotamadya, karena instansi ini bukan instansi yang memiliki kewenangan menindak pelanggaran penggunaan alat tangkap tertentu. Dinas Perikanan Kabupaten sebatas melakukan pembinaan dan penyuluhan (pencegahan) terhadap kemungkinan pelanggaran penggunaan alat tangkap.

Alasan lain yang menjadi argumen soal pelanggaran arad di Pantura adalah keterbatasan sarana-prasarana dalam melakukan pengawasan guna pencegahan penggunaan arad. Di Rembang misalnya, tidak memiliki perahu bermotor yang cukup besar kecuali harus sewa dari Polairud-Polda Jateng di Semarang, dan salah satu sumber dana untuk operasi seringkali dibebankan kepada KUD-KUD. Beberapa KUD-KUD diminta bantuan sumbangan dana untuk biaya operasi penertiban alat tangkap yang dianggap merusak itu.

\section{Soal Keterwakilan Nelayan}

Pengelolaan sumberdaya perikanan di Jawa Tengah cenderung dibebankan pada tingkat propinsi bukan di tingkat kabupaten atau kotamadya. Hal ini dapat dilihat dari jenjang kewenangan institusi baik pemerintah, koperasi nelayan atau organisasi HNSI. Dinas Perikanan Propinsi misalnya, memiliki kewenangan penentuan kebijakan perijinan dan program kegiatan pengelolaan yang diselenggarakan di kabupaten dan kotamadya, terutama dalam penentuan kebijakan yang berkaitan dengan pengelolaan TPI. Kegiatan perikanan yang strategis di daerah kabupaten atau kotamadya justru masih dikuasai oleh daerah propinsi. Di lain pihak, Dinas Perikanan Kabupaten hanya ditempatkan sebagai instansi pelaksana dan pemantau terhadap implementasi kebijakan dan program yang datang dari Dinas
Perikanan Propinsi. Kecenderungan menempatkan organisasi koperasi di tingkat propinsi sejajar Dinas Perikanan Propinsi terlihat dengan memberikan peranan yang besar kepada Pusat Koperasi Unit Desa (PUSKUD), PUSKUD adalah gabungan koperasi perikanan (KUD MINA) yang berada di beberapa kabupaten di Jawa Tengah. Kewenangan PUSKUD di Jawa Tengah terlihat dari pengelolaan pajak setoran dari kegiatan TPI yang diberikan kepada PUSKUD yang berkedudukan di Semarang. PUSKUD mendapat bagian 3,15\% dari retribusi Tempat Pelelangan Ikan. Selain itu bagian tersebut digunakan untuk dana paceklik nelayan, dana asuransi, biaya penyelenggaraan lelang termasuk gaji karyawan dan administrasi pengelola TPI, dan biaya perawatan dan pengembangan sarana dan sewa TPI.Kecenderungan pengelolaan perikanan seperti ini jelas merupakan inisiatif pemerintah untuk mendorong kebijakannya dan memfasilitasi pengendaliannya terhadap pasar (TPI), dan bukan inisiatif masyarakat itu sendiri.

Belum ada organisasi masyarakat nelayan yang dapat dikategorikan sebagai stakeholder dalam pengelolaan sumberdaya perikanan. KUD dan HNSI belum dapat dikatakan sebagai stakeholder masyarakat nelayan. KUD dan HNSI telah gagal sebagai wakil komunitas nelayan. $\quad \mathrm{M}$ a s y a r a k a t nelayan yang berada di pedesaan telah terpecah ke dalam ikatan-ikatan sosial berdasarkan kelompok kepentingan organisasi perkotaan yang didirikan bukan sepenuhnya beranggotakan nelayan. Akibatnya organisasi itu tidak berakar di kalangan masyarakat nelayan. Organisasi ekonomi nelayan yang namanya KUD MINA misalnya, memiliki jalur organisasi sendiri di masyarakat desa nelayan, demikian juga organisasi HNSI juga memiliki jalur organisasi sendiri di tingkat masyarakat. Masing-masing organisasi memiliki wadah di tingkat pedesaan, ini berarti bahwa masyarakat nelayan telah terpecah-pecah ke dalam 
beberapa kelompok organisasi yang bukan dikelola oleh nelayan. Kelompok nelayan ini dalam kenyataannya hanya sekedar wadah berhimpun yang dimanfaatkan sebagai kepentingan organisasi. Sebab kedua organisasi nelayan ini, hidupnya tidak tergantung dari hasil tangkapan ikan nelayan menjadi anggota, melainkan dari pajak yang di pungut dari kegiatan pelelangan ikan di TPI. KUD tidak merasa "bersalah" jika koperasi ini tidak memberikan sesuatu manfaat kepada anggota. Selain itu, dalam prakteknya nelayan anggota KUD tidak pernah memberikan setoran kepada KUD seperti iuran wajib, atau iuran pokok sebagai layaknya anggota koperasi. Jadi dengan demikian, yang terjadi tidak ada ikatan emosional antara KUD dan nelayan yang tercatat sebagai anggota KUD.

Demikian pula di Jawa Barat, contohnya di komunitas nelayan Babakan, Cirebon. KUD Mina memang ada di daerah ini, akan tetapi tidak berfungsi sebagaimana yang seharusnya, yaitu melayani kebutuhan nelayan. Oleh karena itu keberadaan KUD Mina tidak pernah diakui oleh nelayan setempat. Secara formal organisatoris KUD Mina memang memiliki beberapa unit kegiatan, mulai dari unit pelelangan ikan sampai perkreditan. Akan tetapi kenyataannya, semua itu tidak ada kegiatannya. Satu-satunya kegiatan KUD yang berjalan hanyalah memungut retribusi penjualan teri nasi. Secara teoritis hasil retribusi tersebut digunakan untuk keperluan nelayan, seperti dana paceklik, dana kecelakaan, dan lain-lain. Akan tetapi kenyataannya juga dana-dana tersebut tidak pernah sampai kepada nelayan. Dengan demikian KUD hanyalah merupakan perpanjangan tangan pemerintah daerah untuk memungut retribusi, tanpa memperhatikan aspirasi anggota KUD.

Hal tersebut di atas terjadi karena adanya intervensi pemerintah (Pemda) yang membuat KUD Mina menjadi tidak pernah mandiri. Sebagai contoh adalah adanya ketentuan dalam Perda No. 11 tahun 1999, yang menyebutkan bahwa pengelolaan keuangan KUD harus pegawai negeri. Oleh karena itu, manager atau pengelola KUD di daerah tersebut adalah seorang Kepala Cabang Dinas Kecamatan Babakan. Adanya ketentuan yang demikian, maka jelas seorang pengelola KUD tidak akan berorientasi untuk kepentingan anggotanya.

Dengan kenyataan tersebut di atas, tampaknya dapat dikatakan bahwa stakeholder tersebut tidak bertindak semestinya sebagai wakil dari nelayan. Dalam kasus pengoperasian jaring cotok ini, KUD tidak mau tahu tentang persoalan yang dihadapi nelayan kecil di dalam memperjuangkan kepentingannya. Demikian juga, HNSI belum dapat dikatakan memperjuangkan nelayan kecil. HNSI masih terbatas upaya membantu penanganan kasus-kasus konflik fisik yang menimpa nelayan. Lebih daripada itu, setelah dilakukan sosialisasi peraturan yang melarang jaring arad, HNSI hanya menunggu nelayan mempunyai kesadaran sendiri untuk tidak menggunakan alat tangkap tersebut.

Untuk itu perlu melakukan identifikasi karakteristik komunitas nelayan. Identifikasi karakteristik komunitas nelayan tersebut sangat penting untuk meminimalkan konflikkonflik kepentingan di dalam pengelolaan sumberdaya perikanan. Ketika nelayan dengan alat tangkap yang sangat terbatas dan menghasilkan tangkapan ikan yang minimal, maka dorongan untuk melakukan praktik penangkapan secara destruktif menjadi besar. Hal itu menimbulkan motivasi bagi setiap orang untuk semakin meningkatkan kuantitas dan kualitas eksploitasinya. Eksploitasi yang berlebihan ini mengakibatkan semakin menurunnya ketersediaan sumberdaya laut. Menurunnya sumberdaya laut akibat eksploitasi yang berlebihan ternyata semakin meningkatkan kompetisi perburuan sumberdaya laut, tak terkecuali dengan cara destructive fishing. Cara penangkapan tersebut yang kemudian menjadi akar konflik dari perbedaan alat tangkap. Selain 
merupakan konflik yang disebut Charles (1992) sebagai konflik alokasi internal. Konflik tersebut juga dapat disebut sebagai konflik akibat kerusakan lingkungan yang disebabkan oleh praktek satu pihak yang merugikan nelayan lain (Satria, 2006).

Konflik tersebut juga seringkali disinyalir sebagai konflik primordial, yang dipicu oleh penerapan otonomi daerah. Upaya pengusiran nelayan A terhadap B lalu dianggap sebagai bentuk pengkavlingan laut. Begitu pula pengusiran nelayan tradisional terhadap nelayan trawl yang merupakan konflik kelas. Padahal konflik yang terjadi tidak ada hubungannya dengan otonomi daerah. Bahkan kebanyakan nelayan sendiri juga tidak mengerti apa itu otonomi daerah. Oleh sebab itu, perencanaan pengelolaan perikanan yang dilakukan secara sentralistik di tingkat propinsi akan semakin menjauhkan dari aspirasi dan kepentingan masyarakat nelayan, dan kebijakan pengelolaan sumberdaya perikanan akan selalu tidak memberikan kewenangan satuan-satuan adminsitrasi pemerintah yang langsung berhadapan dengan masyarakat nelayan.

\section{KESIMPULAN DAN IMPLIKASI KEBIJAKAN}

\section{Kesimpulan}

1. Permasalahan umum dalam Perikanan Tangkap di Pantura Jawa yaitu penggunaan jaring arad/cotok oleh nelayan.

2. Penggunaan jaring arad tersebut banyak menimbulkan konflik berdimensi perorangan antar warga masyarakat dan antar kelompok nelayan yang tak kunjung selesai.

3. Alat tangkap yang digunakan bukan merupakan identitas sosiokultural suatu komunitas nelayan.

4. Langkah penyelesaian masalah sudah dilakukan dengan mengeluarkan Peraturan Pemerintah yang melarang penggunaan jaring arad. Namun demikian masih lemahnya pada taraf implementasinya di lapangan sehingga penggunaan masih tinggi, seperti masih lemahnya penegakan aturan petugas, sarana prasarana, belum berfungsinya organisasi nelayan seperti KUO, HNSI. Hal ini karena KUD, HNSI belum merupakan cerminan solidaritas nelayan, karena permasalahan dan aspirasi nelayan pun tidak direspon oleh organisasi tersebut.

\section{Implikasi Kebijakan}

Pembentukan organnisasi komunitas nelayan (Civil Society Organization) dengan memilih pengurus yang mewakili karakteristik kemajemukan komunitas nelayan. Diharapkan dapat menyampaikan aspirasi serta dapat melakukan perencanaan pengelolaan dan pelaksaan kegiatan yang sesuai dan dapat memperjuangkan aspirasi serta kepentingan nelayan.

\section{DAFTAR PUSTAKA}

Charles, A.T. 1992. Fishery Conflicts : A Unified Framework in Marine Policy, 16(5): 379393. (1992).

Indrawasih, R.(ed). 2003. "Kebijakan Pengelolaan Sumberdaya Laut : Pelajaran dari Kabupaten RembangJawa Tengah". PMB-LIPI. Jakarta.

Satria, A. 2006. "Konflik Nelayan", makalah yang dipresentasikan dalam Seminar Hasil-hasil Penelitian PMB-LIPI 19 Setember 2006.

Wahyono, A. dkk. 2001. "Pemberdayaan Masyarakat Nelayan". Media Presindo, Yogyakarta.

Adullah, Nurdin. 2006. "Kualitas Sumberdaya I k a T T r u n $25 \%-30 \%$ " (http://www.bisnis.com/servlet/page? pageid $=477 \&$ dad portal30 \& schema=PORTAL30\&pared id $=4358$ 37\&patop id=W09, Selasa 2 Mei 2006, diakses 19 Februari 2009).

Kompas. Sabtu, 28 April 2001. Konflik Belum Teratasi, Nelayan Resah (http://www2 
. kom pas. c o m / k o m p a s cetak/0104/28/daerah/ konf19. htm, diakses 18 Mei 2009).

Suara Merdeka. Selasa, 7 Oktober 2003. Ikan Hasil Tangkapan Merosot Tajam Garag a r a J a ring A $r$ a d (http://www.suaramerdeka.com/ harian/ 0310/07/dar3.htm diakses $18 \mathrm{Mei}$ 2009).

Suprapto, Hanni V, Thoha D. 2001. "Konflik Warnai Nelayan Pantura", http://www2.kompas.com/kompascetak/ 0105/15/daerah/konf2 1. h t m, Selasa 15 Mei 2001 . Diakses 19 Februari 2009.

Sundaya, Yuhka. 2009, Fakta Illegal Fishing di Indramayu dan Konsep Penegakkan. http://mukhtar api.blogspot.com /2009/03/ fakta-illegal-fishing-diindramayu-dan.html (diakses 18 mei 2009) 